American Journal of Environmental Sciences 8 (1): 42-55, 2012

ISSN 1553-345X

(C) 2012 Science Publications

\title{
Determining Potential Sites for Runoff Water Harvesting using Remote Sensing and Geographic Information Systems-Based Modeling in Sinai
}

\author{
${ }^{1}$ Hossam H. Elewa, ${ }^{2}$ Atef A. Qaddah and ${ }^{3}$ Ayman A. El-Feel \\ ${ }^{1}$ Department of Water Resources, National Authority for Remote Sensing and Space Sciences (NARSS), \\ 23 Jozef Brows Tito St., El Nozha El Gedida, 11769, P.O. Box 1564 (Alf-Maskan), Cairo, Egypt \\ ${ }^{2}$ Environmental GIS Lab, Egyptian Environmental Affairs Agency (EEAA), \\ Tera'at El Mansuriyah St., El-Mansura, Egypt \\ ${ }^{3}$ GIS and Remote Sensing Lab, Egyptian Mineral Resources Authority (EMRA), \\ 3 Salah Salem St., Abassia St., Cairo, Egypt
}

\begin{abstract}
Problem statement: Sinai is increasingly suffering from an overwhelming water crisis. Runoff Water Harvesting (RWH) could be a solution for this problem. The determined promising drainage basins for RWH could be used by the decision makers to propose appropriate controlling systems to overcome the problem of water scarcity and for implementing runoff farming and rain-fed agriculture. Approach: Remote sensing, geographic information systems, watershed modeling system were integrated to extract a multi-criteria-decision support system of nine thematic layers, namely; volume of annual flood, lineaments frequency density, drainage frequency density, maximum flow distance, basin area, basin slope, basin length, average overland flow distance and soil infiltration. These criteria were used for conducting a Weighted Spatial Probability Modeling (WSPM) to determine the potential areas for the RWH. The potential runoff available for harvesting was estimated by applying Finkel-SCS rainfall-runoff methods. Results: The WSPM classified Sinai into four classes that graded from high $\left(3,201-6,695 \mathrm{~km}^{2}\right)$, moderate $\left(35,923-35,896 \mathrm{~km}^{2}\right)$, low $\left(13,185-16,652 \mathrm{~km}^{2}\right)$, very low $\left(1.38-5.57 \mathrm{~km}^{2}\right)$ for RWH. Promising watersheds like those of Abu Taryfya, Hamma El Hassana, Gerafi, Watir, Geraia, Heridien, Sidri, Feiran and Alaawag, are categorized as high-moderate RWH potential basins. Conclusion: These basins could be investigated in detail with larger scale to determine the appropriate locations for implementing the RWH structures and techniques. Implementing systems and techniques of RWH in the potential watersheds could open new opportunities for sustainable development in the area.
\end{abstract}

Key words: Watershed modeling, drainage systems, hydrographic parameters, water resources scarcity, runoff calculations, spatial modeling

\section{INTRODUCTION}

The water scarcity is a major socio-economic crisis in Sinai Peninsula of Egypt (Fig. 1). Lack of proper water resources planning led to the drastic dropdown in Sinai urbanization and population development. Drought management, as well as sustainable agricultural production in arid and semiarid areas of Sinai deserts will depend heavily on meticulous planning in the exploration, exploitation and utilization of water resources for favoring the human requirements. The agrarian system in Wadi ElArish delta and the coastal belt in northern Sinai is to a large extent, rainfall dependent, which in turn is highly erratic in nature. This calls for an intervention of a framework where Remote Sensing (RS), Geographic Information Systems (GIS) and watershed modeling tools could be useful in determining potential areas for Rainwater Harvesting (RWH). Planning should be based on the drainage basins, where effective methodologies and systematic information on the resources base are opt to quantify, analyze and formulate targets of water resources development by RWH.

Since 1982, the Egyptian government has promoted Sinai's tourism industry, but repositioning the newly formed settlements and urban communities are hampered mainly by the water scarcity.

Corresponding Author: Hossam H. Elewa, National Authority for Remote Sensing and Space Sciences (NARSS), 23 Jozef Brows Tito St., El Nozha El Gedida, 11769, P.O. Box 1564 (Alf-Maskan), Cairo, Egypt 


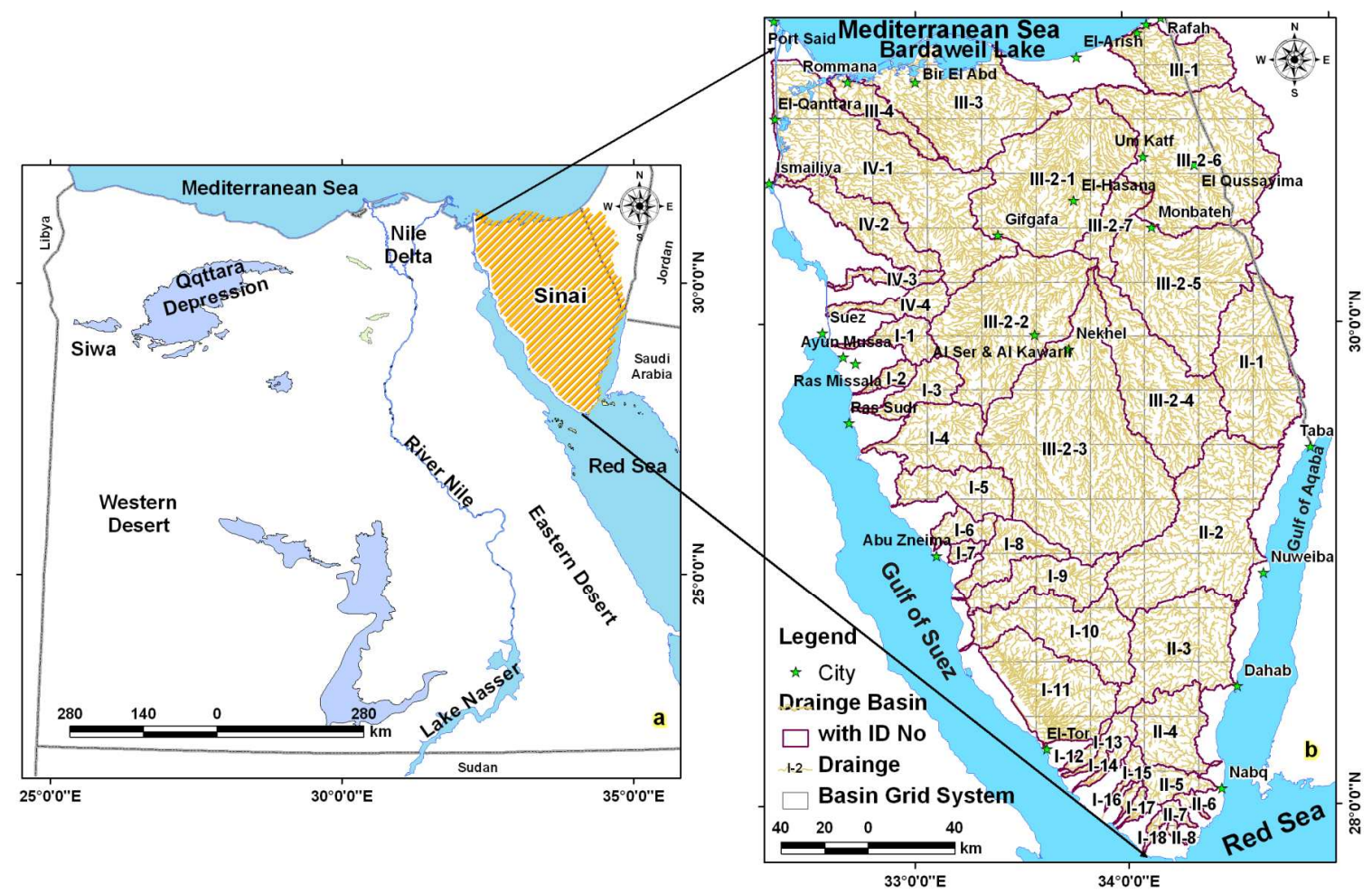

Fig. 1: a Location map, $b$ drainage net map of study area (Extracted from Landsat ETM + image and GIS techniques)

Worth mentioning, no perennial surface water streams cross the peninsula and the flash floods, in spit the fact that they are episodic and intermittent; no full utilization for them is performed. The groundwater resources in Sinai are relatively renewed by the sporadic rainfalls and flash floods occurring at its southern parts during the transitional periods between spring and autumn.

The Sinai Peninsula is located in the northeastern portion of Egypt and is bounded by longitudes $32^{\circ} 20^{\prime}$ $34^{\circ} 52^{\prime} \mathrm{E}$ and latitudes $27^{\circ} 45^{\prime}-31^{\circ} 10^{\prime} \mathrm{N}$. It occupies an area of about $61,000 \mathrm{~km}^{2}$ or about $6 \%$ of Egypt's total area with a population of about 400,000 , which is mainly Bedouin (60\%) and the rest are located in small cities such as El-Arish and Sharm El-Sheikh. The Peninsula has a triangular shape; its apex is to the south at Ras Mohammed (south of latitude $28^{\circ}$ ), whereas its base is to the north extending along the Mediterranean Coast between Port Said and Rafah for about $210 \mathrm{~km}$ (Fig. 1). Sinai is bounded in the eastern side by the Gulf of Aqaba and the international border and in the west by the Gulf of Suez and the Suez Canal. The peninsula has over $900 \mathrm{~km}$ of coasts, including about $155 \mathrm{~km}$ along the eastern bank of the Suez Canal. Sinai history is intertwined with many societies. Previous settlers include the ancient Egyptians, Nabataea's, Romans,
Byzantines and Bedouin. Their experience in water harvesting and exploitation can teach basic lessons to the new settlers of the late twenty one century (Dames and Moore, 1982).

Rainwater harvesting can reduce the use of drinking water for landscape irrigation and sanitation. It is also an effective water conservation tool and proves more beneficial when coupled with the use of native, low-water-use and desert-adapted plants. Additionally, rainwater is available free of charge and puts no added strain on the municipal supply or private wells. Furthermore, groundwater recharge or deep drainage percolation is a hydrologic process where rainwater moves downward to the groundwater. This process usually occurs in the vadose zone below plant roots and is often expressed as a flux to the water table surface. Recharge occurs both naturally (through the water cycle) and anthropologically (i.e., artificial groundwater recharge), where rainwater and or reclaimed water is routed to the subsurface.

The concept of water harvesting as a solution for providing water to arid environments has a long history in Egypt. The northeastern coast and the North Sinai's areas have long traditions in runoff farming. Remnants from Roman times are frequently found (FAO, 1994). 
Some wadi terracing structures have been in use for over centuries. In Wadi El Arish region of Egypt, stone dykes were used to direct the runoff water flow for irrigation purposes. Also cisterns, which store water for animal and human consumption as well as for supplemental irrigation, are common in Egypt. The number of cisterns has increased from less than 3,000 in 1960 to about 15,000 in 1993 with a capacity of about 4 million $\mathrm{m}^{3}(\mathrm{FAO}, 1994)$. Ironically, North Sinai has plenty of underground water and rainfall would be sufficient, if it were harvested, to support as many as a million people in the area.

In comparison with the Middle East practices, archaeological evidence of water harvesting structures appears in Jordan, Israel (Negev), Palestine, Syria and Iraq (Evenari et al., 1982). Researchers have found signs of early water harvesting structures believed to have been constructed over 9000 years ago in the Edom Mountains in southern Jordan. The outstanding importance of the Middle East in the development of ancient runoff farming through water harvesting techniques is unquestioned (Pereira, 1996). The Negev's most productive period in history however, began with the arrival of the Nabataea's and other desert dwellers late in the 3rd century B.C to establish rich civilizations in the desert 2,000 years ago (Hillel, 1992; Evenari et al., 1982). Runoff farming continued throughout Roman rule and reached its peak during the Byzantine era (Pereira, 1996). Water harvesting systems come in a variety of implementations, but the common components are invariably a catchment or source area, a storage facility and target or use area. For such systems the storage facility is either the soil's root zone for immediate or a small reservoir for later use.

Various studies relating the geology, geomorphology and water resources in Sinai Peninsula were helpful in our study among them: (Hammad, 1980); El Shamy (1992); GSE, 1994; FAO (1994) and Shalaby (1996).

Dames and Moore (1982) in association with the Egyptian Industrial Development Programs presented an overview of Sinai Peninsula environment taking into consideration the development potential of the peninsula's lands and water resources, with principal emphasis on the runoff potentialities of important hydrographic basins. Ahmed et al. (2002) reviewed the harvesting of irregular rainfall outside the Nile Valley and Delta. The review covered the hydrological, rainfall and groundwater recharge processes. The study reviewed methods of runoff harvesting, sets a framework for comparing these methods from a technical perspective and identifies how these techniques should be applied. On the other hand, many researchers had dealt the issue of water harvesting, by using the conventional methods of surface water qualitative techniques, like investigating the relationships of geomorphometric parameters. El Shamy (1992) proposed appropriate controlling systems in Wadi El Arish hydrographic basin, which he (op. cit.) stated that the proposed structures should be started at the upstream tributaries of the hydrographic system using simple retardation stony dams. These dams are supposed to promote the groundwater recharge to the existing pervious and fractured rock formations and allow a slow controlled runoff into the downstream areas. Ashmawy et al. (2000) investigated the flash floods hazards of Sinai's drainage basins through analyzing the morphometric characteristics of drainage network and basins. He (op. cit.) assorted the drainage basins in respect to the possible surface runoff potentiality.

Geomorphologic features of sinai peninsula: The peninsula is divided into a number of distinct geographic zones. In the north, a strip of loose sand and dunes runs inland from the coast for 16 to $32 \mathrm{~km}$ and then gives way to a flat, barren plain. This gravel and limestone plain continues for nearly $241 \mathrm{~km}$, rising at its southern extremity to the Plateau of Gebel Al-Tih. From this plateau to the southern tip of the peninsula, Sinai is cut by a jagged system of mountains and wadies (channels that fill with water during rainstorms) (Fig. 1).

Sinai Peninsula is divided into five main geomorphologic units. These units are the southern elevated mountains, the plateau of central Sinai, the conspicuous unit of northern Sinai, mountainous and hilly areas of North Sinai and the Gulf of Suez coastal plain.

The southern part of Sinai is occupied by the high mountains complex, such as the Gebel Catherina $(2,641$ $\mathrm{m}$ amsl), Um Shomar (2,586 m amsl) and Serbal (2,070 $\mathrm{m}$ amsl). To the north of this mountain mass, occurs the great Egma limestone plateau, which slopes from more than 1,000 m downwards to the Mediterranean Sea. The southern mountainous is highly dissected by watersheds draining either to the Gulf of Suez or to the Gulf of Aqaba, whereas most of the drainage basins of the northern plateau are debouching northwards to the Mediterranean Sea (Fig. 1). Hydro-morphometric parameters used for determining the potential areas for RWH are given in Table 1. 
Am. J. Environ. Sci., 8 (1): 42-55, 2012

Table 1: WMS hydro-morphometric output parameters used for determining the potential areas for RWH and the input criteria of the WSPM

\begin{tabular}{|c|c|c|c|c|c|c|c|c|c|c|}
\hline $\begin{array}{l}\text { Basin ID } \\
\text { (Fig. 1b for } \\
\text { locations) }\end{array}$ & or Wadi (Valley) name & $\begin{array}{l}\text { Basin } \\
\text { area }\left(\mathrm{km}^{2}\right)\end{array}$ & $\begin{array}{l}\text { Basin } \\
\text { slope }(\mathrm{m} / \mathrm{m})\end{array}$ & $\begin{array}{l}\text { Basin } \\
\text { length (m) }\end{array}$ & $\begin{array}{l}\text { Average } \\
\text { overland flow } \\
\text { distance }(\mathrm{m})\end{array}$ & $\begin{array}{ll}\text { W } & \text { Max.flow } \\
\text { distance }(m)\end{array}$ & $\begin{array}{l}\text { Volume of annual } \\
\text { flood }\left(1000 \mathrm{~m}^{3}\right) \\
\text { (Finkel method) }\end{array}$ & $\begin{array}{l}\text { Volume of } \\
\text { Annual flood } \\
\text { ( } \mathrm{m}^{3} / \text { year) (SCS } \\
\text {-CN method) } \\
\text { Elewa and } \\
\text { Qaddah, 2011) }\end{array}$ & $\begin{array}{l}\text { Total runoff } \\
\left(\mathrm{m}^{3} / \text { year) }\right. \\
\text { (Elewa and } \\
\text { Qaddah, 2011) }\end{array}$ & $\begin{array}{l}\text { Runoff loss by } \\
\text { infiltration } \\
\left(\mathrm{m}^{3} / \text { year) }\right. \\
\text { (SCS-CN } \\
\text { method) } \\
\text { (Elewa and } \\
\text { Qaddah, 2011) }\end{array}$ \\
\hline I & $\begin{array}{l}\text { Eastern gulf of suez } \\
\text { drainage system }\end{array}$ & & & & & & & & & \\
\hline $\mathrm{I}-1$ & El Raha & 440.27 & 0.10920 & 48730 & 782 & 84260 & 1564 & 3207946 & 5410139 & 2202193 \\
\hline $\mathrm{I}-2$ & Lahata & 192.50 & 0.12292 & 32510 & 743 & 44628 & 897 & 658762 & 1184701 & 525939 \\
\hline $\mathrm{I}-3$ & Sudr & 601.14 & 0.09155 & 53801 & 836 & 81685 & 1927 & 2315391 & 4268910 & 1953519 \\
\hline I-4 & Wardan & 1186.26 & 0.10579 & 60073 & 846 & 90161 & 3040 & 4170575 & 7705180 & 3534605 \\
\hline $\mathrm{I}-5$ & Gharandal & 920.32 & 0.14694 & 57115 & 798 & 105562 & 2564 & 3925466 & 7202295 & 3276829 \\
\hline I-6 & Tayba & 356.43 & 0.11862 & 33693 & 875 & 50972 & 1357 & 1342286 & 2444935 & 1102649 \\
\hline I-7 & Matala & 119.97 & 0.12037 & 19797 & 863 & 29399 & 651 & 822791 & 1325254 & 502463 \\
\hline I- 8 & Baba & 719.74 & 0.14152 & 55207 & 983 & 75483 & 2173 & 3153539 & 5685007 & 2531468 \\
\hline I-9 & Sidri & 1075.16 & 0.15817 & 79271 & 868 & 111291 & 2846 & 5749065 & 10748927 & 4999862 \\
\hline $\mathrm{I}-10$ & Feiran & 1776.29 & 0.20014 & 81695 & 849 & 138938 & 3984 & 14024982 & 25353243 & 11328261 \\
\hline $\mathrm{I}-11$ & Alaawag & 1924.66 & 0.19998 & 57255 & 969 & 80868 & 4204 & 13403688 & 24520208 & 11116520 \\
\hline $\mathrm{I}-12$ & Imlaha & 136.83 & 0.13351 & 33797 & 1112 & 39080 & 712 & 437229 & 779984 & 342755 \\
\hline I-13 & Isla & 276.24 & 0.31925 & 45308 & 873 & 56105 & 1144 & 570850 & 1078629 & 507779 \\
\hline I-14 & Thoman & 149.93 & 0.26281 & 35915 & 983 & 42500 & 757 & 282433 & 543858 & 261425 \\
\hline $\mathrm{I}-15$ & El_Mahash & 169.16 & 0.29427 & 38211 & 838 & 44896 & 824 & 362561 & 657802 & 295241 \\
\hline I-16 & Lethei & 74.46 & 0.14089 & 24443 & 972 & 28640 & 473 & 35437 & 84136 & 48699 \\
\hline I-17 & Ghashi & 106.48 & 0.19595 & 23577 & 1016 & 28474 & 522 & 51543 & 120364 & 68821 \\
\hline I-18 & El At El Gharbi & 79.77 & 0.10322 & 21421 & 1166 & 24113 & 495 & 52286 & 123943 & 71657 \\
\hline S & $\begin{array}{l}\text { Eastern sinai drainage } \\
\text { System (Gerafi and } \\
\text { Gulf of Aqaba) }\end{array}$ & & & & & & & & & \\
\hline II-1 & Gerafi & 2353.66 & 0.03266 & 71902 & 848 & 102281 & 4810 & 10643109 & 20055825 & 9412716 \\
\hline II-2 & Watir & 3522.97 & 0.14959 & 76211 & 822 & 123594 & 6303 & 1394351 & 12720526 & 11326175 \\
\hline II-3 & Dahab & 2071.41 & 0.22795 & 57586 & 818 & 96197 & 4416 & 8620926 & 16563557 & 7942631 \\
\hline II-4 & Kid & 1044.48 & 0.35417 & 47759 & 772 & 70992 & 2791 & 3851731 & 7187315 & 3335584 \\
\hline II-5 & Umm Adawi & 364.16 & 0.26751 & 36068 & 876 & 50093 & 1377 & 1068761 & 1933830 & 865069 \\
\hline II-6 & Sasir & 83.42 & 0.10176 & 19268 & 1117 & 23823 & 511 & 50138 & 128972 & 78834 \\
\hline II-7 & El At El Sharki & 107.63 & 0.22902 & 19964 & 905 & 26902 & 609 & 75217 & 174363 & 99146 \\
\hline II-8 & Madsus & 39.11 & 0.20526 & 14145 & 840 & 18368 & 308 & 23295 & 49546 & 26251 \\
\hline III & $\begin{array}{l}\text { North sinai } \\
\text { drainage system }\end{array}$ & & & & & & & & & \\
\hline III-1 & El Kharoba & 1232.70 & 0.02167 & 59124 & 896 & 32382 & 694 & 8556596 & 15790980 & 7234384 \\
\hline III-2 & El Arish & & & & & & & & & \\
\hline III-2-1 & El Hamma El Hasana & 3590.29 & 0.05988 & 85571 & 833 & 36902 & 640 & 16234425 & 28578308 & 12343883 \\
\hline III-2-2 & El Bruk & 3299.23 & 0.02756 & 90989 & 837 & 29224 & 602 & 14304144 & 26653440 & 12349296 \\
\hline III-2-3 & Yarqa Abu Taryfya & 6345.60 & 0.05607 & 138390 & 727 & 23174 & 495 & 42593062 & 66788359 & 24195297 \\
\hline III-2-4 & El Fetahy El Aqaba & 2544.64 & 0.04140 & 104550 & 740 & 17908 & 447 & 14405379 & 25474092 & 11068713 \\
\hline III-2-5 & Geraia & 3083.58 & 0.03718 & 81676 & 802 & 21253 & 571 & 16066820 & 28723209 & 12656389 \\
\hline III-2-6 & Heridien & 3905.03 & 0.06372 & 94398 & 871 & 143023 & 2676 & 14792676 & 26569987 & 11777311 \\
\hline III-2-7 & Central Wadi El Arish & 613.32 & 0.03362 & 46710 & 858 & 77870 & 2746 & 3098567 & 5558633 & 2460066 \\
\hline III-3 & Bardawil Sector & 3332.33 & 0.03959 & 64960 & 853 & 154676 & 1246 & 9309031 & 15888333 & 6579302 \\
\hline III-4 & East Bardawil Sector & 583.85 & 0.04291 & 65234 & 836 & 90078 & 1140 & 1894991 & 3537143 & 1642252 \\
\hline IV & $\begin{array}{l}\text { Eastern suez canal } \\
\text { drainage system }\end{array}$ & & & & & & & & & \\
\hline IV-1 & Salam & 4453.93 & 0.04026 & 137533 & 822 & 216541 & 1271 & 20442227 & 32131868 & 11689641 \\
\hline IV-2 & Umm Khashieb & 1082.41 & 0.04193 & 87417 & 806 & 124626 & 1303 & 4888073 & 8641240 & 3753167 \\
\hline IV-3 & El Giddi & 276.98 & 0.05810 & 55069 & 802 & 76453 & 1600 & 955100 & 1803290 & 848190 \\
\hline IV-4 & El Hagg & 482.29 & 0.06464 & 57812 & 801 & 73526 & 1763 & 2526852 & 4321224 & 1794372 \\
\hline
\end{tabular}

\section{MATERIALS AND METHODS}

The different stream networks and basins in Sinai are studied here to compute its hydro-morphological and hydrological parameters to assess their surface water potentialities and determining RWH effective sites. Accordingly, the present study describes a process for determining site characteristics and developing an integrated approach including Remote Sensing (RS), Geographic Information System (GIS) and Watershed Modeling System (WMS) for performing such objective.

Digital Elevation Model (DEM) with $30 \mathrm{~m}$ resolution of the study area has been obtained from the ASTER (Advanced Spaceborne Thermal Emission and
Reflection) (Akl, 2005), which was subsequently enhanced by the topographic contours and spot heights.

The geometric parameters of the watersheds were determined using Watershed Modeling System (WMS) software AQUAVEO, 2009, which delineates the basins and provides multiple watershed characteristics. Accordingly, nine thematic maps, viz. Volume of Annual Flood (VAF), Average Over land Flow Distance (OFD), Maximum Flow Distance (MFD), Rock or Soil Infiltration (SI), Drainage Frequency Density (DFD), Basin Area (BA), Basin Slope (BS), Basin Length (BL) and Lineaments Frequency Density (LFD) were integrated as input layers for the Weighted Spatial Probability Model (WSPM) to perform a 
determination for the efficient sites suitable for the RWH. The WMS software calculated the hydromorphometric characteristics for each watershed value used in WSPM. These values are provided for each of the delineated watersheds in Table 1. These multi layers were manipulated within the ArcGIS 9.3.3 ® software spatial analyst module (ESRI, 2009).

The geological map of Conoco, 1987 was used to extract the surface rock cover to identify the soil types. The interpretation of Enhanced Thematic Mapper Plus (ETM+) satellite image mosaic (taken in 2006) using ERDAS Imagine 9.3.1® software Leica Geosystems GIS and LLC. Mapping, 2008 had led to an additional enhancement for the extraction of lineaments.

Two runoff calculation models were used; the Soil Conservation Service-Curve Number (USDA) (1989) and the Golany (1979) methods, which were run inside the WMS 7.3 software AQUAVEO, 2009. However, the two methods have their advantages or disadvantages according the conditions of their application. Golany (1979) used his method for the Araba Valley, which was adopted in similar climatic conditions that could be similar to those of Sinai. It is a simple graphical method to determine the probability or frequency of occurrence of yearly or seasonal rainfall. On the other hand, some researchers (Hjelmfelt, 1980; Ponce and Hawkins, 1996; Fennessey et al., 2001; Mishra and Singh, 2003; Geetha et al., 2007; Young, 2011) have pointed out limitations and cautions to the use of the SCS-CN method for estimating runoff. The concerns include the limited regional extent (Midwestern) and landscape (agricultural) in which it was developed, discontinuous and subjective Antecedent Moisture Condition (AMC), somewhat arbitrary selection of initial abstraction and applicable size of catchment is restrictive. Accordingly, we used the two methods for runoff estimation for comparison, verification and validation purposes.

The empirical method (Golany, 1979) uses the following parameters (Eq. 1 and 2).

Peak flood flow (Qmax):

$$
\mathrm{Q}_{\max }=\mathrm{K}_{1} \mathrm{~A}^{0.67}
$$

where, Qmax = Peak flood flows, in $\mathrm{m}^{3} / \mathrm{sec}$

Volume of annual flood (v) in 1000 cubic meters:

$$
\mathrm{V}=\mathrm{K}_{2} \mathrm{~A}^{0.67}
$$

where, $\mathrm{A}$ is the area of the basin in $\mathrm{km}^{2}$ and $\mathrm{K}_{1}$ and $\mathrm{K}_{2}$ are constants depending on probability of occurrence:

Probability of occurrence $K_{1} \& K_{2}$ in a given year was taken as $10 \%$ or $1.58 \& 26.5$ for $\mathrm{K}_{1} \& \mathrm{~K}_{2}$, respectively.
Here we used $10 \%$ because it is very suitable for the developmental conditions.

On the other hand, the SCS-CN model for estimating the volume of runoff (USDA 1989; Hogarth et al., 2004; Jain and Sinha, 2003; Tyagi et al., 2008; Elewa and Qaddah, 2011) was used. The peak flood discharge for various recurrence storm intervals of ten years in the studied watersheds using the DEM data and weighted $\mathrm{CN}$ generated from the existing land use and soils data was calculated by the WMS software. The major environmental factors associated with the rainfall-runoff processes are involved in the SCS-CN method. These factors include the watershed characteristics, rainfall, evaporation, evapotranspiration and runoff. The SCS-CN method is based on the water balance equation and two hypothetical equations such as the proportional equality and linear relationship between the initial abstraction and potential maximum retention (Mishra and Singh, 2003). Then the calculation of direct runoff, Q, by the SCS-CN method can be expressed as (Eq. 3):

$Q=\frac{\left(P-I_{a}\right)^{2}}{\left(P-I_{a}\right)+S}=\frac{(P-0.2 S)^{2}}{P+0.8 S}$

where, Eq. (3) is valid for $\mathrm{P} \geq \mathrm{Ia}, \mathrm{Q}=0$. $\mathrm{S}$ is determined on the $\mathrm{CN}$ by Eq. 4:

$\mathrm{S}=\frac{25,400}{\mathrm{CN}}-254$

Where:

$\mathrm{P}=$ Total rainfall in $\mathrm{mm}$

Ia = Initial abstraction

$\mathrm{Q}=$ Excess rainfall or direct runoff volume (direct runoff depth in $\mathrm{mm}$ )

$\mathrm{S}$ = Maximum potential abstraction of water by soil in $\mathrm{mm}$. Potential maximum retention when runoff begins

$\mathrm{S}=$ Expressed in terms of a scale parameter

$\mathrm{CN}=$ Which can vary between $0-100$ representing zero storage or $100 \%$ runoff

$\mathrm{CN}=$ The hydrologic soil cover complex runoff curve number (non-dimensional) (USDA, 1989)

The hydromorphometric criteria adopted in the present study to determine the suitability of different areas of Sinai Peninsula for conducting RWH are based, with modifications, on the previous similar studies, which have been found to correlate highly with peak discharge and runoff volumes (Oweis et al., 2001; Morisawa, 1962; Gregory and Walling, 1973). 


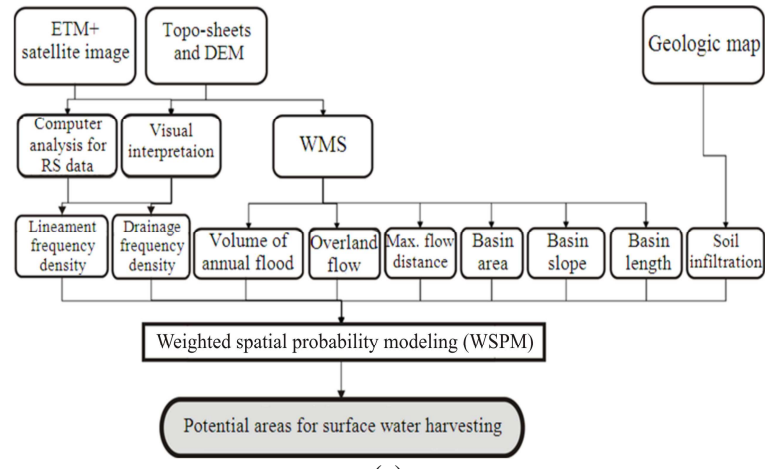

(a)

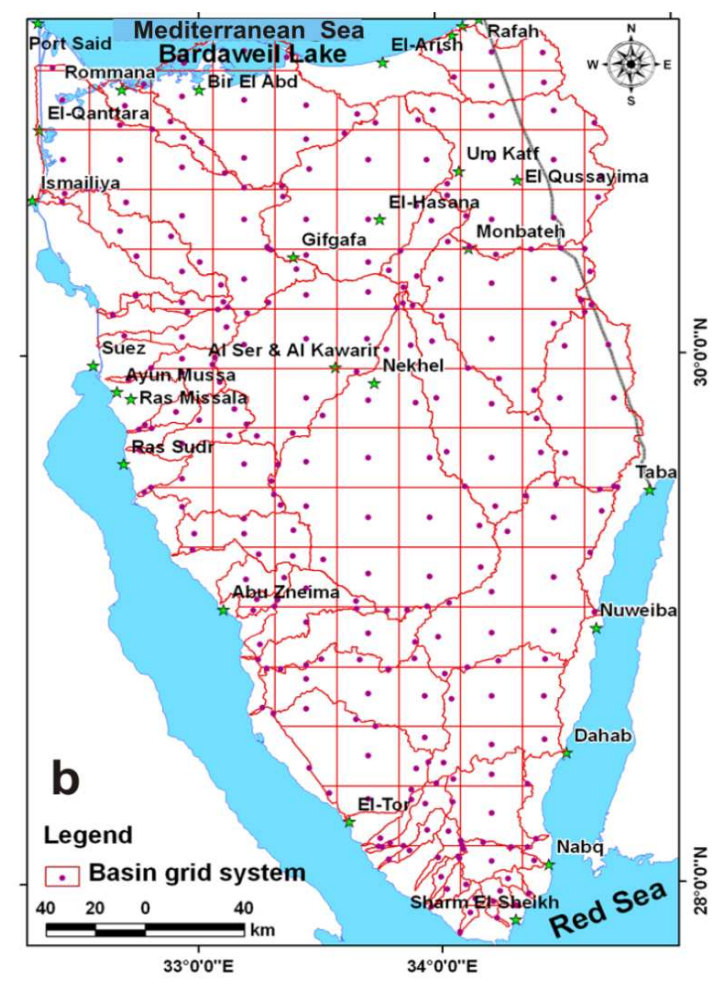

(b)

Fig. 2: a Flowchart of methodology; b Grid system $(625 \mathrm{~km} \times 625 \mathrm{~km})$ used in mapping and WSPM techniques

The main hydromorphometric parameters deduced from the WMS include using the GIS thematic layers of VAF, OFD, MFD, SI, DFD, BA, BS, BL and LFD in performing the WSPM for determining the potential areas for RWH (Table 1). Subsequently, a Weighted Spatial Probability Model (WSPM) was constructed using the prepared multi-layer GIS, to classify the study area into four gradational rainwater harvesting (RWH) potential areas. The overall flowchart of methodology is given in Fig. 2.

\section{RESULTS}

After defining basin attributes with the DEM inside the platform of WMS, the multi criteria decision support layers previously discussed are converted to data coverage for easier data storage and manipulation. The ranges of these input layers used in the WSPM are given in Table 2. A short description of the different parameters computed and stored in the data coverage is given below:

Integration of these criteria in the GIS-based WSPM will result in confidential maps for the efficient sites suitable for RWH, with a number of classes.

\section{DISCUSSION}

The following is a short discussion of the nine criteria used for the construction of the WSPM maps.

Volume of Annual Flood (VAF) criterion: The success or failure of RWH depends to a great extent on the quantity of water that can be harvested from an area under given climatic conditions. Sinai regions vary in climate from arid-tropical, to Mediterranean and to mountain-temperate, due to its long coasts and mountains. It is generally a land of little rain. These rainfalls happen twice yearly, where they are collected in wide collectors and debouched to the wadies ended at both Gulfs of Suez and Aqaba. Essentially no summer precipitation falls in Sinai and the total precipitation falls between November and March. Here the mean number of days receiving precipitation in a year is twenty, compared to fifteen at Port Said and five at Nikhil and Taba. It is generally assumed that higher mountains including Zebir, Musa and Serbal receive more than $100 \mathrm{~mm}$ UNESCO, 1977. The driest part of the Peninsula lies along the Plain of Qa'a. El Tor receives a scant $13 \mathrm{~mm}$ per year. The second driest area extends up to the coastal plain along the Gulf of Aqaba, with receipts gradually increasing from a low of approximately $15 \mathrm{~mm}$ at Sharm el Sheikh on the Red Sea to $20 \mathrm{~mm}$ at Taba near the head of the Gulf.

Data of rainfall amounts used in the calculation of VAF were compiled from the available records of published and unpublished sources (NSG, North Sinai Governorate, 2006: Environmental assessment of North Sinai, Cooperation project between Egypt and Danish Governments. unpublished, 322 pp) and Elewa and Qaddah (2011).

The VAF two thematic maps constructed by Golany (1979) and USDA (1989) methods classified the Sinai area into five classes according to their potentiality for $\operatorname{VAF}\left(\mathrm{m}^{3} / \mathrm{yr}\right.$.). 
Am. J. Environ. Sci., 8(1): 42-55, 2012

Table 2: Ranges of input criteria used for the WSPMs

\begin{tabular}{|c|c|c|c|c|c|}
\hline Watershed criteria & Very high & High & Moderate & Low & Very low \\
\hline Basin area $\left(\mathrm{Km}^{2}\right)$ & $>4634$ & $4633-3541$ & $3540-2845$ & $2844-1752$ & $<1751$ \\
\hline Basin length $(m)$ & $>97414$ & 97413-79978 & 79977-72559 & $72558-55123$ & $<55122$ \\
\hline Basin slope $(\mathrm{m} / \mathrm{m})$ & $<0.039$ & $0.04-0.044$ & $0.045-0.063$ & $0.064-0.128$ & $>0.129$ \\
\hline Drainage frequency density (density $\left./ 625 \mathrm{~km}^{2}\right)$ & $>222$ & $221-162$ & $161-121$ & $120-61$ & $<60$ \\
\hline Lineament frequency density (segment $/ 625 \mathrm{~km}^{2}$ ) & $<3$ & $4-6$ & $7-13$ & $14-29$ & $>30$ \\
\hline Maximum flow distance $(\mathrm{m})$ & $>146888$ & 146887-100482 & $100481-69523$ & $69522-48868$ & $<48867$ \\
\hline Average overland flow distance $(\mathrm{m})$ & $>1002$ & 1001-909 & $908-850$ & $849-812$ & $<811$ \\
\hline Volume of annual flood $\left(1000 \mathrm{~m}^{3}\right)$ & & & & & \\
\hline (by Finkel method) & $>5105$ & $5104-3906$ & 3905-2707 & 2706-1508 & $<1507$ \\
\hline $\begin{array}{l}\text { Volume of annual flood ( } \mathrm{m}^{3} / \text { year) } \\
\text { (by SCS-CN method) }\end{array}$ & $>17135168$ & 17135167-10978412 & 10978411-6870977 & $6870976-4130731$ & $<4130730$ \\
\hline Soil hydrologic Group (USDA, 1989) & $\mathrm{d}$ & $\mathrm{c}$ & $\mathrm{b}$ & $\mathrm{a}$ & \\
\hline
\end{tabular}

Table 3: Ranks and weights for criteria and their influencing classes used for RWH potentiality mapping

\begin{tabular}{|c|c|c|c|c|}
\hline Data layers (Criteria) & RWH potentiality class & $\begin{array}{l}\text { Average rates } \\
\text { (Rank) }\left(\mathrm{R}_{\mathrm{c}}\right)\end{array}$ & Weights $\left(\mathrm{W}_{\mathrm{c}}\right)$ & $\begin{array}{l}\text { Degree of } \\
\text { effectiveness (E) }\end{array}$ \\
\hline Volume of annual & I (Very high) & 90 & & 11.0 \\
\hline \multirow[t]{4}{*}{ flood (VAF) } & II (High) & 70 & & 8.0 \\
\hline & III (Moderate) & 50 & 12 & 6.0 \\
\hline & IV (Low) & 30 & & 4.0 \\
\hline & V (Very low) & 10 & & 1.0 \\
\hline \multicolumn{5}{|l|}{ Average Overland Flow } \\
\hline \multirow{5}{*}{ Distance (OFD) } & I (Very high) & 90 & 11 & 10.0 \\
\hline & II (High) & 70 & & 8.0 \\
\hline & III (Moderate) & 50 & & 6.0 \\
\hline & IV (Low) & 30 & & 4.0 \\
\hline & V (Very low) & 10 & & 1.0 \\
\hline \multirow[t]{5}{*}{ Maximum Flow Distance (MFD) } & I (Very high) & 90 & 11 & 10.0 \\
\hline & II (High) & 70 & & 8.0 \\
\hline & III (Moderate) & 50 & & 6.0 \\
\hline & IV (Low) & 30 & & 4.0 \\
\hline & V (Very low) & 10 & & 1.0 \\
\hline \multirow[t]{4}{*}{ Rock or Soil Infiltration (SI) } & I (Very high) & 90 & 11 & 10.0 \\
\hline & II-III (High-moderate) & 60 & & 6.6 \\
\hline & IV (Low) & 30 & & 4.0 \\
\hline & V (Very low) & 10 & & 1.0 \\
\hline \multirow[t]{5}{*}{ Lineament Frequency Density (LFD) } & I (Very high) & 90 & 11 & 10.0 \\
\hline & II (High) & 70 & & 8.0 \\
\hline & III (Moderate) & 50 & & 6.0 \\
\hline & IV (Low) & 30 & & 4.0 \\
\hline & V (Very low) & 10 & & 1.0 \\
\hline \multirow[t]{5}{*}{ Drainage Frequency Density (DFD) } & I (Very high) & 90 & 11 & 10.0 \\
\hline & II (High) & 70 & & 8.0 \\
\hline & III (Moderate) & 50 & & 6.0 \\
\hline & IV (Low) & 30 & & 4.0 \\
\hline & V (Very low) & 10 & & 1.0 \\
\hline \multirow[t]{5}{*}{ Basin Area (BA) } & I (Very high) & 90 & 11 & 10.0 \\
\hline & II (High) & 70 & & 8.0 \\
\hline & III (Moderate) & 50 & & 6.0 \\
\hline & IV (Low) & 30 & & 4.0 \\
\hline & $\mathrm{V}$ (Very low) & 10 & & 1.0 \\
\hline \multirow[t]{5}{*}{ Basin Slope (BS) } & I (Very high) & 90 & 11 & 10.0 \\
\hline & II (High) & 70 & & 8.0 \\
\hline & III (Moderate) & 50 & & 6.0 \\
\hline & IV (Low) & 30 & & 4.0 \\
\hline & V (Very low) & 10 & & 1.0 \\
\hline \multirow[t]{5}{*}{ Basin Length (BL) } & I (Very high) & 90 & 11 & 10.0 \\
\hline & II (High) & 70 & & 8.0 \\
\hline & III (Moderate) & 50 & & 6.0 \\
\hline & IV (Low) & 30 & & 4.0 \\
\hline & V (Very low) & 10 & & 1.0 \\
\hline
\end{tabular}

Fig. 3a shows the classes of VAF calculated by Finkel's method, where high-very high classes $\left(>3,906 \mathrm{~m}^{3} / \mathrm{yr}\right.$.) occur mostly along an axis trending SW-E-NE and parallel to the Gulf of Aqaba-International borders. They include the watersheds of Alaawag, Feiran, in the eastern
Gulf of Suez drainage System and the watersheds of Watir, Gerafi and Dahab in the Eastern Sinai Drainage System (Tables 1-2; Fig. 3a).

The moderate class $\left(2,707-3,905 \mathrm{~m}^{3} / \mathrm{yr}\right.$.) of VAF is represented by the watersheds of Wardan, Sidri in the 
Eastern Gulf of Suez Drainage System and the watersheds of Kid in the Eastern Sinai Drainage System. The low-very low VAF classes (< 2,706 $\mathrm{m} 3 / \mathrm{yr}$.) are encountered in the central-northern Sinai. The representative basins of these classes are El-Raha, Lahata, Sudr, Gharandal, Tayba, Matala, Baba, Imlaha, Isla, Thoman, El Mahash, Leithei, Ghashi, El At El Gharbi of Eastern Gulf of Suez Drainage System and the watersheds of Umm Adawi, Sasir, El At El Sharki, Madsus of the Eastern Sinai Drainage System and the watersheds of El-Kharoba, El Hamma El Hassana, El Bruk, Yarqa Abu Taryfya, El Fetahy El Aqaba, Geraia, Heridien, Bardawil Sector, East Bardawil Sector of North Sinai Drainage System.

On the other hand little shift in the spatial distribution of VAF classes was observed in case of the VAF map constructed by the SCS-CN method (1989) (Fig. 3b), where the area occupied by the very high $(>17,135,168$ $\mathrm{m}^{3} / \mathrm{yr}$.) was shrunken to a small areas in central and northwestern Sinai (i.e., a part of Wadi Abu Taryfya), whereas the high class of VAF was enlarged to comprise a larger area in north-northeastern and central Sinai. However, areas of low-very low classes occurring in north-northwestern parts encountered by Fig. 3a are replaced by the moderate-low VAF classes in Fig. 3b (Fig $3 a-b$; Table 1-2). This layer was assigned a weight of 12 in the WSPM (Table 3; Fig. 3a-b).

Lineament Frequency Density (LFD) criterion: Lineament analysis for RWH potentiality mapping has considerable importance, where the joints and fractures enhance the rock or soil infiltration. Accordingly, the higher the LFD, the lower the RWH potentiality and vice versa.

The lineaments were extracted through the visual interpretation of the satellite ETM + data (acquired in 2006) and were confirmed by matching with the structures and lineaments indicated by the geological map Conoco, 1987. The lineament density was expressed by classifying the area into specific frames $(25 \times 25 \mathrm{~km})$ and thus the number of lineaments in each grid cell was automatically counted and the resulted value was plotted in the mid-point of each cell, producing a grid map with nodes and attribute values (Fig. 2b). From the grid map, contour lines could be drawn to reflect the lineament density.

The resulting LFD map with five classes referring to the lineament density or number of lineaments per unit area $\left(625 \mathrm{~km}^{2}\right)$ was produced. The five LFD classes in this study were < 3, 4-6, 7-13, 14-29 and > 30 lineament/625 $\mathrm{km}^{2}$, for very high, high, moderate, low and very low for the RWH, respectively (Fig. 3c).
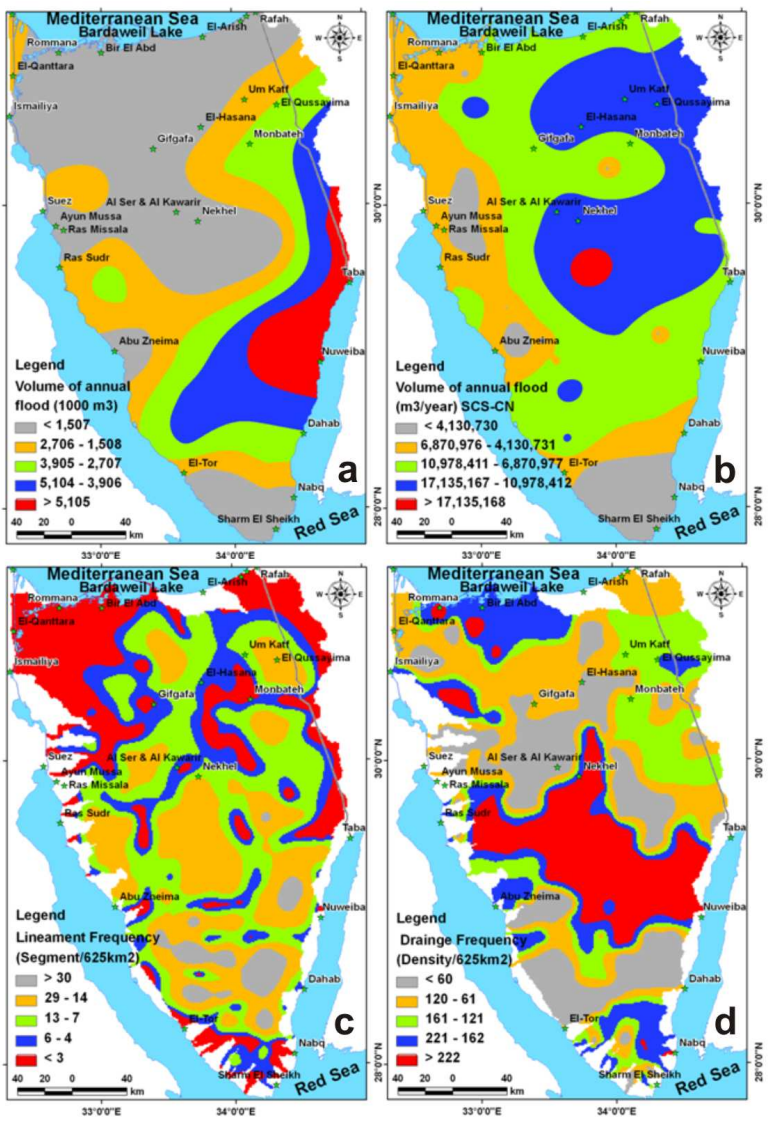

Fig. 3: GIS thematic layers used in the WSPM: a Volume of annual flood calculated by Finkel's method (Golany, 1979); b Volume of annual flood calculated by SCS-CN method (USDA, 1989); c Lineaments frequency density; d Drainage frequency density

High-very high LFD classes (> 14/625 $\mathrm{km}^{2}$ ) are occurred within the fractured basement territory of southern Sinai, whereas the density decreases away from this territory towards north and south (Fig. 3c). This layer was assigned a weight of 11 in the WSPM (Table 3).

Drainage Frequency Density (DFD) criterion: A map for the drainage network was prepared from the DEM of $30 \mathrm{~m}$ spatial resolution, topographic maps at 1:250,000 scale and satellite ETM + data (Fig. 1b).

Following the same technique and grid system used for the construction of the LFD map, a map for the DFD has been prepared, where the drainage segments were counted within the grid system (Fig. 2b).

The rate of runoff loss by infiltration is controlled by the DFD. The higher the DFD the higher the RWH potentiality and vice versa. 

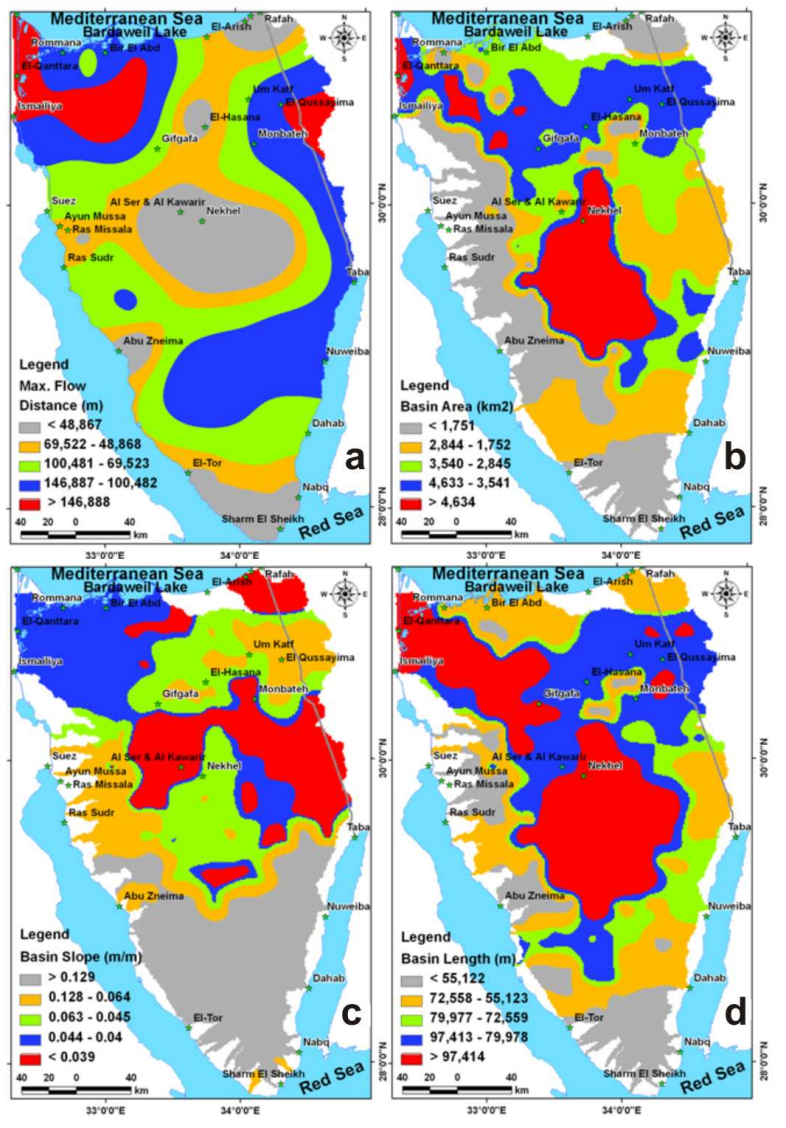

Fig. 4: GIS thematic layers of: a Maximum flow distance; b Basin area; c Basin slope; $d$ Basin length

The resulting DFD map was also assigned to five classes by following the same approach used in preparation of the LFD map (Fig. 3d).

The DFD classes were ordered as: > 222, 221-162, 161-121, 120-61, >60 segment/625 km², for very high, high, moderate, low and very low for RWH, respectively (Tables 1-2; Fig. 3d). This layer was given a weight of 11 in the WSPM (Table 3 ).

Maximum Flow Distance (MFD) criterion: It is defined as the Maximum Flow Distance (MFD) within a basin including both overland and channel flow (Horton, 1945). It is the maximum length of the water's path in the drainage basin $(\mathrm{m})$.

This factor is important in determining the RWH capability of a drainage basin, as the higher the MFD the more chances available for RWH. It is also a function of the basin area. The constructed thematic map of the MFD criterion indicated the very high-high classes occupied the southern central-extreme eastern parts (watersheds of Watir, Sidri, Feiran, Gerafi, Heridien) with maximum flow distance ranges from 100,482 to more than $146,888 \mathrm{~m}$. the very high-high classes are also occur at the northwestern part of Sinai (i.e., Bardawil sector, Salam, Umm Khashieb), which are underlain by the old River Nile branch (the Pelusium). The very low class of the MFD is established in northern-central parts, which encompasses parts of Wadi El-Arish upstream (i.e., watersheds of El Fetahy El Aqaba, El Bruk, Yarka Abu Taryfya, El-Hamma El Hassana, El-Kharoba). Additionally, the small basins characterized by lowvery low MFD classes $(<69,522 \mathrm{~m}$ ) are also found at the extreme southern parts of the peninsula (i.e., watersheds of Umm Adawi, Sasir, El At El Sharki, El At El Gharbi, Madsus, Imlaha, Isla, Thoman, El Mahash, Lethei, Ghashi) (Fig. 1b; Table 1-2). This layer was assigned a weight of 11 in the WSPM (Table 3; Fig. 4a).

Basin area criterion: Basin area (A) is defined as the total area in square kilometers enclosed by the basin boundary (Horton, 1945). Basin area has been identified as the most important of all the morphometric parameters controlling catchment runoff pattern. This is because, the larger the basin, the greater the volume of rainfall it intercepts and the higher the peak discharge that result (Morisawa, 1959; Pitlick, 1994). Another reason for the high positive correlation between basin area and discharge is the fact that basin area is also highly correlated with some of the other catchment hydromorphometric characteristics which influence runoff, such as, basin length (the larger the basin, the longer its length), average overland flow distance and maximum flow distance (Gregory and Walling, 1973; Ebisemiju, 1976) and (Jain and Sinha, 2003). The thematic layer for basin area with five classes was generated (Fig. 4b). The very high basin area class $\left(>4,634 \mathrm{~km}^{2}\right)$ occurs in one of Wadi El-Arish upstream sub-watersheds (Yarqa Abu Taryfya) with $6345.6 \mathrm{~km}^{2}$ and in some small patches at the northwestern part of Sinai in South El-Qantarra-west Bir Gifgafa area (Salam watershed). The high and moderate basin area classes $\left(4633-2845 \mathrm{~km}^{2}\right)$ are represented by the northern and eastern watersheds (i.e. Wadies Heridien, El-Hamma El-Hassana, part of Bardawil Sector, ElBruk, Geraia and Watir). The low basin area class (2844-1752 $\mathrm{km}^{2}$ ) is represented by the watersheds of Gerafi, El Fetahy El Aqaba, Dahab and Al-Awag, which occur in eastern Sinai. The very low basin area class $\left(<1751 \mathrm{~km}^{2}\right)$ is represented by the watersheds of Kid, Umm Dawi, Imlaha, Isla, Thoman, El Mahash, Ghashi, Gharandal and El At El Gharbi, which occur in the extreme southern territory of Sinai. The Eastern Gulf of Suez drainage system comprises a larger portion of the very low basin area class, where it comprises the watersheds of Baha, Sudr, Lahata, ElRaha, Wardan, Gharandal, Tayba, Matala, Baba, Sidri 
(Fig. 1b) (Table 1-2). This layer was assigned the weight of 11 in the WSPM (Table 3; Fig. 4b).

Basin Slope (BS) criterion: The slope gradient of the drainage basin is a key factor for the selection of water harvesting locations in order to get the maximum storage capacity in the channel. It is the average slope of the triangles comprising this basin (Horton,1945; Leopold and Maddock, 1953). A triangle's slope is computed as the change in elevation divided by the change in plan distance. It is the average longitudinal slope of the drainage basin, following the water flow. This slope is calculated between the points found at 10 and $85 \%$ of the total distance between the furthest point of the drainage basin outflow (in terms of the water's travel time) and the drainage basin outflow. The slope must be expressed in meters per meters (a 1\% slope is equivalent to $0.01 \mathrm{~m} / \mathrm{m}$ ). Average basin slope is a variable, which is usually not readily apparent. Reasonable care should be taken in determining this parameter as peak discharge and hydrograph shape are sensitive to the value used for basin slope (Jones, 1997). Slope plays a very significant role in determining infiltration vs. runoff. Infiltration is inversely proportional to slope, i.e. the water infiltration decrease with the increase in slope steepness. In the present study, slope map is generated from the DEM. Five slope classes were generated. The slope map was merged with the basin map to create slope attributes of each drainage basin. The thematic layer of BS indicates an increase in value due south in the mountainous terrains in El-Tih and Egma plateau (slope > 0.129) (Fig. 4c).

Whereas, the BS decreases in the central (0.04-0.128) and northern parts $(<0.039-0.063)$ of Sinai Peninsula, which doubles the possibilities of RWH. The possibility of RWH is higher in gentle or medium-sloped basins of central and northern Sinai; in Wadies El-Arish and Gerafi subwatersheds and South El-Qantarra-Bir El-Abd-Rommana Strip. This layer was assigned the weight of 11 in the WSPM (Table 3; Fig. 4c).

Basin Length (BL) criterion: It is the distance which cut the basin into two similar parts (Horton, 1945). The longer the BL, the lower the chances that such a basin will be flooded, if compared with a more compact basin like those occurred in southern and west Sinai (Fig. 4d). (i.e., watersheds of Kid, Umm Adawi, Sasir, El At El Sharki, El At El Gharbi, Imlaha, Isla, Thoman, El Mahash, Lethei, Ghasi, Tayba, Matala, Baba, Lahata, El Raha, El Giddi, El Hagg). This is because, the longer the basin, the lower its slope and hence the higher the possibilities for RWH (Table 1). Micro catchment RWH techniques are more successful in shorter basin lengths, whereas macro catchment procedures are more applicable in longer basin lengths characterizing the central, northern, eastern and southwestern basins of Sinai (Table 1, Fig. 1b). This layer was assigned a weight of 11 in the WSPM (Table 3; Fig. 4d).
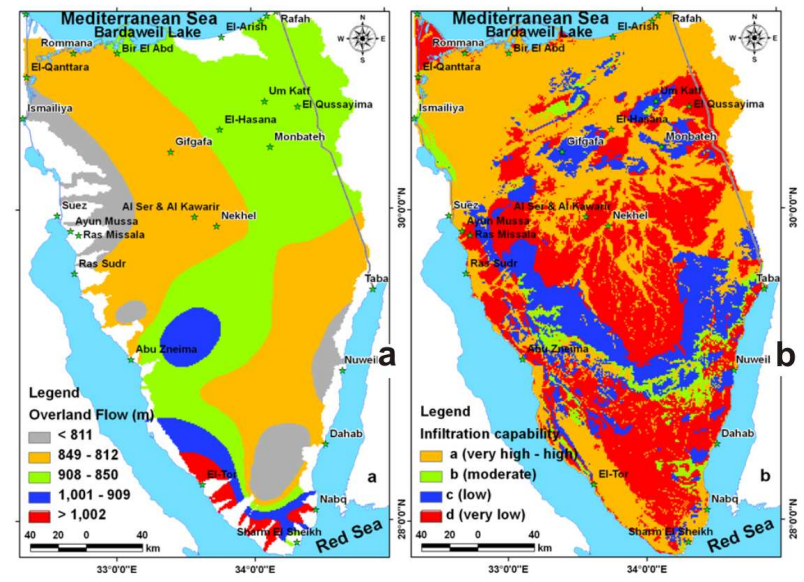

Fig. 5: GIS thematic layers of: a average overland flow distance; b Soil infiltration capability

Average Overland Flow Distance (OFD) criterion: The average Overland Flow Distance (OFD) within the basin is computed by averaging the overland distance traveled from the centroid of each triangle to the nearest stream. The overland flow is the water that flows over the slopes of the drainage basin and is then concentrated into stream channels.

Upon reaching the channel, it is called surface runoff. Also, it is known as surface flow (Horton, 1945). The Sinai Peninsula includes a full range of drainage basin types, with varying relief and slope, which determine where overland is effective and generated. It is also affected by the type of lithology of surface topography, which governs the erosion rates by overland flow (Montgomery and Dietrich, 1989). The thematic layer of the average OFD indicates a pronounced increase in the southwestern-southern parts (> $909 \mathrm{~m}$ ) (high-very high class), which were occupied by the watersheds of Sasir in the Eastern Sinai drainage system and watersheds of Baba, Alaawag, Imlaha, Isla, Thoman, Lethei, Ghashi and El At El Gharbi of the Eastern Gulf of Suez drainage System (Fig. 5a; Table 1-2). The lowvery low average OFD classes $(<849 \mathrm{~m})$ characterize the watersheds of Umm Khashieb, Gerafi, El-Giddi, ElHagg, El-Raha, Lahata, Salam, El-Bruk, Feiran, Wardan, Watir, Kid, Dahab, Madsus and Gharandal, etc. The moderate class of OFD (850-908 $\mathrm{m}$ ) is occupied by watersheds of Matala, Sidri of Eastern Gulf of Suez Drainage System and the watersheds of El-Kharoba, Central Wadi El Arish, El-Hamma El Hasana, Heridien, Geraia, El Fetahy El Aqaba and Yarqa Abu Taryfya of North Sinai Drainage System and the watersheds of Umm Adawi and El At El Sharki of the Eastern Sinai Drainage System. However, this map reflects the effect of infiltration capability of the sub terrain soil, where the 
segregation of Sinai Peninsula into different classes with different infiltration capabilities (Fig. 5a) gave good reasons behind the spatial distribution of average OFD. Accordingly, the very low and low average OFD occurs in areas characterized by very high and high infiltration capability and vice versa (Fig. 5a-b). This layer was assigned a weight of 11 in the WSPM (Table 3; Fig. 5a).

Rock or Soil Infiltration (SI) criterion: The layer of rock or soil infiltration is essential to understand the nature and distribution of infiltration capabilities of surface rock units (Hasmadi et al., 2010). The SI determines whether the water will infiltrate or rather runoff over the soil surface.

The classification of lithologic formations according to their infiltration capabilities or signatures was carried out depending on intensive previous investigations or previous work NARSS, 2009 and references therein), in addition to the Soil Groups based on the USDA soil classification scheme USDA, 1989 (Table 2). Thus, a map with four classes was produced to reveal rock formations of similar infiltration properties or lithologic groups A, B, C and D. According to these groups, infiltration rates decreases from A to D, which is inversely related to the RWH capabilities for the same group. In the obtained classification, soil or rock groups of similar hydrologic properties were embedded in one map (Fig. 5b). The classified map with four classes was used instead of the five classes, as the SI class B includes both high and moderate infiltration capabilities. This layer was assigned a weight of 11 in the WSPM (Table 3).

Weighted Spatial Probability Modeling (WSPM): The Multi-Criteria Decision Support System (MCDSS) represented by the previously discussed nine thematic layers, were ranked according to their magnitude of contribution to RWH, thus they were categorized from very high to very low contribution and the same classes were used in the RWH potentiality mapping (Table 3; Fig. 6). Two WSPM were conducted, where the model was run twice; one with the VAF calculated by Finkel and the other by the SCS-CN runoff models. The model's running implied the integration of all criteria as thematic layers in the WSPM. Accordingly, two output maps will be obtained by the WSPM with a number of classes indicating the categories of RWH potentiality (e.g. high, moderate, low,). However, all the previously discussed criteria have the same magnitude of contribution on RWH potentiality, except the criterion of VAF, which have a relatively higher weight of contribution on RWH, as it represents the actual expected available runoff water to be harvested (Table 3 ). However, some criteria work positively while others work negatively in RWH potentiality mapping.
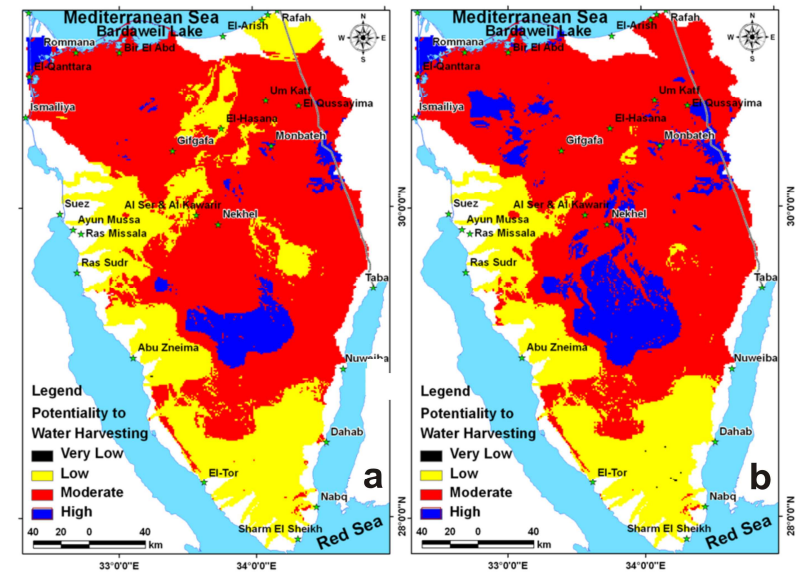

Fig. 6: WSPM maps showing the potential areas for RWH; (a) using Finkel's method for VAF calculation; (b) using SCS-CN method for VAF calculation

Consequently, the BS, LFD and SI criteria work negatively in RWH, whereas the criteria of VAF, OFD, BA, BL, DFD and MFD work positively.

The weights and rates were assumed and optimized for the multi decision support criteria depending on the experience or judgments of the authors and the opinions of experts in the previous similar works on RWH potentiality mapping (i.e., qualitative methods, for example Hasmadi et al. (2010); Sadrolashrafi et al. (2008), in addition to the geostatistical normalization and cross-validation (quantitative methods) within the ArcGIS platform before running the model (Isaaks and Srivastava (1990); Fernandez-Aviles et al. (2011). The cross validation is a statistical procedure for testing the quality of a predicted data distribution and the model results. In cross validation, a piece of data whose value is known independently is removed from the dataset and the rest of the data is used to predict its value. Full cross validation is done by removing, in turn, each piece of data from the dataset and using the rest of the data to predict its value. The weights and rates were determined depending on the magnitude of contributions between each layer range of the WSPM classified layers. Accordingly, the integrated criteria were given the following weights: VAF $(12 \%)$ and other parameters were given (11\%). After proposing criteria weights, categorization was applied to each of the five classes among each criterion. For example, the classes graded from I (very high potential) up to $\mathrm{V}$ (very low potential) according to their importance in RWH potentiality mapping (Table 3 ).

Taking $100 \%$ as a maximum value for the rank, thus for the five classes, ranks will be classified as 100$80,80-60,60-40,40-20$ and $20-0 \%$, respectively. 
Am. J. Environ. Sci., 8 (1): 42-55, 2012

Table 4: Areas of RWH potentiality classes

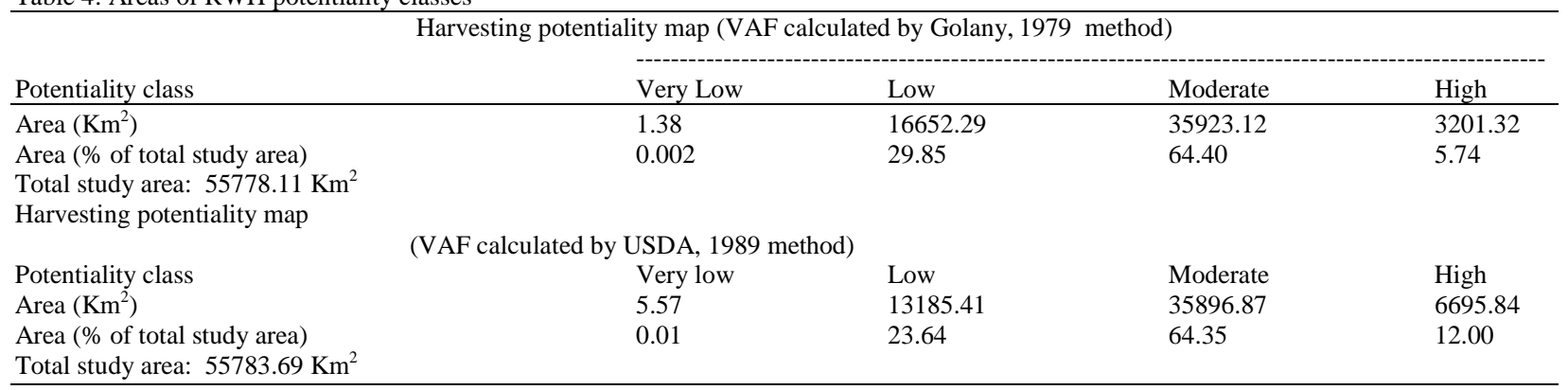

Consequently, the average of ranking for each class will be $90,70,50,30$ and $10 \%$ for classes from I-V, respectively (Table 3 ).

In order to calculate the degree of Effectiveness (E) for each criterion, from the criterion Weight (Wc) and criterion Rank (Rc), the weight was multiplied by the Rank $(\mathrm{Wc} \times \mathrm{Rc})$. For example, if the weight of VAF equals $12 \%$ and this is multiplied by the average rank of 90 , (for class I), the degree of effectiveness will be (Eq. 5):

$\mathrm{E}=\mathrm{Wc} \times \mathrm{Rf}=0.12 \times 90=11$

where, as for the BA criterion, for example, the degree of effectiveness in class I will be: $90 \times 0.11=10$.

According to this method of data manipulation, assessment of the effectiveness of each decision criterion provides a comparative analysis among the different thematic layers. Therefore, it is clear from Table 3 that class I in the VAF criterion (i.e., $\mathrm{E}=11$ ) represents the most effective criterion with regard to the RWH potentiality mapping, compared to the least influencing of class $\mathrm{V}$ (i.e., $\mathrm{E}=1$ ) in all criteria.

Therefore, an arithmetic overlay approach built into ArcGIS 9.3.1 Spatial Analyst Model Builder was carried out for performing the WSPM. This overlay processing manipulates both continuous and discrete grid layers and the derived data are continuous grid data layer. Two output maps for RWH potentiality with four classes ranging from very low to high potentiality were obtained. The spatial distribution of these classes relative to the total area studied is as: 0.002 (very low), 29.85 (low), 64.40 (moderate) and $5.74 \%$ (high) for RWH potentiality map constructed using the VAF criterion calculated by the Finkel's method (Fig. 6a; Table 4) and as: 0.01 (very low), 23.64 (low), 64.35 (moderate), 12\%, for the map constructed using the VAF criterion calculated by the SCS-CN method (Fig. 6b; Table 4). From these two WSPM output maps, it is clear that there is a good correlation between them.

From this point of view, the WSPM resulted in two maps that indicated the Sinai's overall moderate RWH potentiality, especially, in it's the central and northern parts. The present study confirms the results reached by
Elewa and Qaddah (2011), where they elucidated that the Sinai is characterized by an overall moderate groundwater potentiality $(52.29 \%$ of its total area). This moderate groundwater potentiality class occurs within the promising areas characterized by moderate RWH potentiality class resulted from the present study. However, it is logic that the rainfall-rich watersheds are expected to be promising areas in either groundwater or runoff potentialities.

\section{CONCLUSION}

Remote sensing, watershed modeling and GIS techniques are modern research tools that proved to be effective in mapping, investigation and modeling. These tools were used to determine the potential sites or areas for Runoff Water Harvesting (RWH) in Sinai Peninsula. The performed WSPM segregated the peninsula into four potential classes for RWH that ranges from very low to high. The areas of high potential for RWH are occupying only 5.74-12.0\% $\left(3,201-6,695 \mathrm{Km}^{2}\right)$, whereas the areas of low potential for RWH are existing in 23.64-29.85\% (13,185-16,652 $\mathrm{Km}^{2}$ ) of the total Sinai's area. However, most of Sinai's area $64.35-64.40 \% \quad\left(35,923.12-35,896.87 \mathrm{~km}^{2}\right)$ is represented by the moderate potentiality class. For these facts and according to the overwhelming water crisis in Sinai, RWH becomes an important alternative for providing water that could be valuable for implementing runoff farming and rain-fed agriculture along the promising catchments or ephemeral streams of Sinai. Promising watersheds characterized by high and moderate RWH potentiality, i.e., Yarqa Abu Taryfya, El Hamma El Hassana, Gerafi, Watir, Geraia, Heridien, Sidri, Feiran and Alaawag, could be investigated in detail with larger scale to determine the appropriate locations for implementing the RWH structures and techniques. These studies should be performed in parallel with soil investigation to plan for some sorts of micro-catchment rain-fed-agriculture. The rain fed agriculture is already a common practice in the northern coastal areas of Sinai in Kharoba-Sheikh Zuwaid-El-Arish-Rafah strip. Additionally, RWH could 
be used as a tool for flash flood hazard mitigation at the downstream by impounding water in some places upstream. The study came to a conclusion that the potential of RWH in the study area exists and implementing systems and techniques in the promising watersheds could open new opportunities for the sustainable development in the area.

\section{ACKNOWLEDGEMENT}

The researchers wish to express their gratitude to the National Authority for Remote Sensing and Space Sciences (NARSS) for funding a research project from which the data of the present study was extracted.

\section{REFERENCES}

Ahmed, T.A., M.S. El-Manadely and K.M. Soliman, 2002. Integration and Management of Irrigation, Drainage and Flood Control. Proceedings of the 18th International Congress on Irrigation and Drainage, (ICID’ 02), Montreal, Canada.

Akl, P.G., 2005. Temporal change detection using ASTER and USGS digital elevation models. 1st Edn., San Jose State University, pp: 86.

Ashmawy, M.H., A.H. Swedan and T. Abdel Fatah, 2000. Flash flood hazards of drainage basins of Sinai Peninsula, Egypt. Annals Geol. Surv.

Dames and Moore, 1982. Sinai Development Study, Phase I: Draft Final Report: Executive Summary. 1st Edn., Center for International Development and Technology, California, pp: 15.

Ebisemiju, F.S., 1976. The structure of the interrelationship of drainage basin characteristics. Ph.D. Thesis, University of Ibadan.

El Shamy, I.Z., 1992. Towards the water management in Sinai Peninsula. Proceedings of the 3rd Conference Geology, (CG' 92), Sinai Development, Ismailia, Egypt, pp: 63-70.

Elewa, H.H. and A.A. Qaddah, 2011. Groundwater potentiality mapping in the Sinai peninsula, Egypt, using remote sensing and GIS-watershed-based modeling. Hydrogeol. J., 19: 613-628. DOI: 10.1007/s 10040-011-0703-8

ESRI, 2009. ARC User. 1st Ed., Environmental Systems Research Institute, Redlands.

Evenari, M., L. Shanan and N. Tadmor, 1982. The Negev: The Challenge of a Desert. 2nd Edn., Harvard University Press, Cambridge, ISBN-10: 0674606728 pp: 437.

FAO, 1994. Water Harvesting for Improved Agricultural Production. 1st Edn., FAO, Rome, pp: 424.
Fennessey, L.A.J., A.C. Miller and J.M. Hamlett, 2001. Accuracy and precision of NRCS models for small watersheds. J. Am. Water Resou. Assoc., 37: 899912. DOI: 10.1111/j.1752-1688.2001.tb05521.x

Fernandez-Aviles, G., J.M. Montero and J. Mateu, 2011. Mathematical Genesis of the SpatioTemporal Covariance Functions. J. Math. Stat., 7: 37-44. DOI: 10.3844/jmssp.2011.37.44

Geetha, K., S.K. Mishra, T.I. Eldho, A.K. Rastogi and R.P. Pandey, 2007. Modifications to SCS-CN method for long-term hydrologic simulation. J. Irrig. Drain. Eng., 133: 475-486. DOI: 10.1061/(ASCE)0733-9437(2007)133:5(475)

Golany, G., 1979. Arid Zone Settlement Planning: The Israeli Experience. 1st Edn., Pergamon Press, pp: 567.

Gregory, K.J. and D.E. Walling, 1973. Drainage Basin Form and Process: A Geomorphological Approach. 1st Edn., Wiley, London, ISBN-10: 0470151986 pp: 456.

Hammad, F.A., 1980 Geomorphological Hydrogeological Aspects of Sinai Peninsula. A.R.E. Ann. Geol. Surv. Egypt.

Hasmadi, I.M., Pakhriazad, H.Z. and F.S. Mohamad, 2010. Geographic Information System-Allocation Model for Forest Path: A Case Study in Ayer Hitam Forest Reserve, Malaysia. Am. J. Applied Sci., 7: 376-380. 10.3844/ajassp.2010.376.380

Hillel, D., 1992. Out of the Earth: Civilization and the Life of the Soil. 1st Edn., University of California Press, Berkeley, ISBN-10: 0520080807 pp: 321.

Hjelmfelt, Jr., AT., 1980. Curve-number procedure as infiltration method. J. Hydraul. Div., 106: 11071111.

Hogarth, W.L., C.W. Rose, J.Y. Parlange, G.C. Sander and G. Carey, 2004. Soil erosion due to rainfall impact with no inflow: A numerical solution with spatial and temporal effects of sediment settling velocity characteristics. J. Hydrol., 294: 229-240. DOI: 10.1016/j.jhydrol.2004.02.014

Horton, R.E., 1945. Erosional development of streams and their drainage basins; hydrophysical approach to quantitative morphology. Geol. Soc. Am. Bull., 56: 275-370. DOI: 10.1130/0016-7606(1945) 56[275:EDOSAT]2.0.CO;2

Isaaks, E.H. and R.M. Srivastava, 1990. An Introduction to Applied Geostatistics. 1st Edn., Prentice Hall PTR, New York, ISBN-10: 0195050126 pp: 592.

Jain, V. and R. Sinha, 2003. Evaluation of geomorphic control on flood hazard through geomorphic instantaneous unit hydrograph. Current Sci., 85: 1596-1600. 
Jones, J.A.A., 1997. Global Hydrology: Processes, Resources and Environmental Management. 1st Edn., Longman, Harlow, ISBN-10: 0582098610 pp: 399.

Leopold, L.B. and T. Maddock, 1953. The hydraulic Geometry of Stream Channels and Some Physiographic Implications. 1st Edn., Washington, U.S., pp: 57.

Mishra, S.K. and V.P. Singh, 2003. Soil Conservation Service Curve Number (SCS-CN) Methodology. 1st Edn., Springer, Dordrecht, ISBN-10: 1402011326, pp: 513.

Montgomery, D.R. and W.E. Dietrich, 1989. Source areas, drainage density and channel initiation, Water Resou. Res., 25: 1907-1918.

Morisawa, M., 1959. Relation Of Morphometric Properties to Runoff in the Little Mill Creek, Ohio, Drainage Basin. 1st Edn., Departnent of Geology, Columbia University, New York, pp: 10.

Morisawa, M.E., 1962. Quantitative geomorphology of some watersheds in the appalachian plateau. Geol. Soc. Am. Bull., 73: 1025-1046. DOI: 10.1130/ 0016-7606(1962)73[1025:QGOSWI]2.0.CO;2

Oweis, T.Y., D. Prinz and A.Y. Hachum, 2001. Water Harvesting: Indigenous Knowledge for the Future of Drier Environments. 1st Edn., ICARDA, Aleppo, Syria, pp: 36.

Pereira, L.S., 1996. Sustainability of Irrigated Agriculture. 1st Edn., Kluwer Academic Publishers, Dordrecht, ISBN-10: 0792339363, PP: 631.
Pitlick, J., 1994. Relation between peak flows, precipitation and physiography for five mountainous regions in the western USA. J. Hydrol., 158: 219-240. DOI: 10.1016/00221694(94)90055-8

Ponce, V.M. and R.H. Hawkins, 1996. Runoff curve number: Has it reached maturity? Hydrol. Eng. ASCE, 1: 11-19. DOI: 10.1061/(ASCE)10840699(1996)1:1(11)

Sadrolashrafi, S.S., T.A. Mohamed, A.R.B. Mahmud, M.K. Kholghi and A. Samadi, 2008. Integrated modeling for flood hazard mapping using watershed modeling system. Am. J. Eng. Applied Sci., $\quad 1$ : 149-156. DOI: $10.3844 /$ ajeassp.2008.149.156

Shalaby, A.S., 1996. Geomorphology and Hydrology of Wadi Watir Basin, South Eastern Sinai. 1st Edn., Egypt, pp: 256.

Tyagi, J.V., S.K. Mishra, R. Singh and V.P. Singh, 2008. SCS-CN based time-distributed sediment yield model. J. Hydrology El Sevier, 352: 388-403. DOI: 10.1016/j.jhydrol.2008.01.025

Young, G., 2011. HYSTAR: Hydrology and sediment transport simulation using time-area method. Ph.D. Thesis, Department of Biological Systems Engineering. 